\title{
Need for palliative care in patients admitted to emergency departments of three tertiary hospitals: evidence from a Latin-American city
}

\section{Abstract}

Background: Emergency departments (ED) serve as a contact point for critically ill patients. According to experience, a fraction of patients visiting ED present with symptoms and require palliative care; however, the prevalence of these patients has not been determined in Peru so far.

Objectives: To estimate the prevalence of advanced disease in patients admitted to ED and identify among them the need for palliative care.

Patients and methods: In the ED of 3 tertiary hospitals in Lima all adult patients had an evaluation of the medical history and an interview with patients or caregivers. The presence of multiple metastases was considered advanced cancer, and dementia, neurological, respiratory, hepatic or cardiac disease with functional dependence or severe deterioration for non-oncological illness. The screening tool was a validated and adapted palliative care questionnaire.

Results: The prevalence of advanced illness was $7.5 \%$ (60 of 797 admissions). The age of patients was 19-96 (median 73.1) years of which $48.3 \%$ were females, $23(39 \%)$ patients had oncological and $37(61 \%)$ patients non-oncological diagnoses. The most frequent symptoms upon admission were dyspnoea, drowsiness, and pain. A total of $13(21.7 \%)$ of patients with advanced disease were already receiving palliative care and $8(13.3 \%)$ had controlled symptoms.

Conclusions: Nearly 1 in 13 patients attending ED of tertiary hospitals has advanced disease, of which $80 \%$ reported the need for palliative care with less than a quarter of them having received it.

Palliat Med Pract 2020; 14, 4: 236-240

Key words: advanced disease, palliative care, need and demand for health services, emergency departments

\section{Introduction}

Emergency departments (ED) are designed to save lives and prevent premature deaths. Despite this, in recent decades, a greater number of patients with advanced chronic diseases (cancer and non-malignant) are requiring palliative care in these services, especial- ly in tertiary care centres [1-5]. Chronic diseases in advanced stage involve high comorbidity, greater consumption of medications, high degree of functional dependence, significant cognitive deterioration and a greater demand for health services. Isolated reports mention that $33 \%$ of patients with advanced disease die in ED [2], 31\% visited ED in their last six months of

\footnotetext{
Address for correspondence:

Pilar Zelma Huamán Manrique

UNMSM. Medicine Faculty, German Amezaga 375, Lima 15081 Lima, Peru

e-mail: pilarzelma.huaman@unmsm.edu.pe
} 
life and $70 \%$ in their last year [3]. Moreover, advanced cancer patients visits in ED considered inadequate in $20 \%$ of cases [6].

During advanced stage of chronic diseases there is no or limited curative response, even with the best available treatment. In these cases, palliative care is indicated and considered right for patients and families $[4,7]$. This care must include relief of somatic and psychological symptoms and emotional and social support; including the early identification of this need, also in ED [8].

The need for palliative care in ED is not adequately known [3]. Reports indicate that $57 \%$ of patients who died in ED (who already had an indication for non-resuscitation) received palliative care [1]. Palliative care has been better studied in cancer patients. Although chronic non-malignant pathologies (organic insufficiencies and neurodegenerative diseases) are more frequent and of longer duration, there are few reports regarding palliative care among this population [9] with few studies conducted in Latin America [10]. The present study aimed at estimating the prevalence of advanced disease among patients admitted to ED of 3 tertiary social security hospitals in Lima, Peru and to identify among them the need for palliative care.

\section{Patients and methods}

A cross-sectional study carried out in 3 tertiary social security hospitals in Lima (Peru), which report 15,000-22,000 admissions per year [11]. The presence of advanced disease was evaluated among patients 18 or more years of age who were admitted to ED during 7 consecutive days in November 2016. Advanced cancer was defined when multiple cerebral, hepatic or pulmonary metastases were present and the confirmation through anatomic pathology. The following situations were considered as advanced non-oncological disease:

1. Previous diagnosis of dementia or neurological disease plus the presence of severe cognitive impairment included according to the Pfeiffer test or total functional dependency as assessed by the Katz index.

2. Chronic renal failure with glomerular filtration rate less than $30 \mathrm{ml} / \mathrm{min}$ plus total functional dependence.

3. Chronic respiratory disease with continuous home oxygen.

4. Liver cirrhosis in stage $\mathrm{C}$ (Child-Pugh scale).

5. Chronic heart failure with a ventricular ejection fraction of less than $20 \%$ [9].

A sample size was calculated to estimate 293 admissions, expected proportion 21\% [12], with a 95\% confidence level, $5 \%$ accuracy and $15 \%$ loss. Repeated admissions in the evaluation week, incomplete data, refusal to participate, death or transfer within the first $24 \mathrm{~h}$ were excluded. All possible participants were selected. Two trained medical students reviewed the daily admissions report or record, one of 5 doctors (2 specialist in internal medicine and 3 in emergency with more than 5 years of experience) requested informed consent, reviewed hospital medical records and interviewed patients or caregiver, filling out a pre-established form. When doubts were encountered these were solved by consensus.

Among patients with advanced disease the need for palliative care was assessed through an adapted semi-structured questionnaire [13], which started with questions regarding the reaction to death and if he/she knew what palliative care was including the demand and use of it. Among those who did not know the term palliative care, this was explained to them. The survey was validated by expert judgment (adequate degree of agreement among 3 specialists, coefficient W of Kendall 0.884) and had acceptable internal consistency (reliability), with a Cronbach's alpha of 0.699 in a pilot test of 20 patients not included in the study. The data was reviewed, coded and processed with the SPSS-IBM 24.00 program, performing descriptive statistical analysis and calculating $95 \%$ confidence intervals. Ethical approval was obtained from the institutional research committee, following principles of good clinical practice.

\section{Results}

During the study period initially 846 patients were admitted to ED with 49 excluded due to different reasons (Fig. 1). A total of 60 (7.5\%, confidence interval 5.5-9.0\%) patients with advanced disease were identified out of 797 admissions. The proportion of patients in hospital 1, 2, and 3 was 340 (43\%), $289(36 \%)$, and $168(21 \%)$, respectively. A total of $37(61 \%)$ of patients had non-oncological diagnoses including renal failure (diabetes), respiratory (pulmonary fibrosis), dementia (Alzheimer's and vascular type), neurological (stroke and trauma), liver cirrhosis (alcoholism), and heart failure. Malignant tumours were diagnosed in $23(39 \%)$ of patients, most frequently located in the genitourinary and digestive system (Fig. 2).

The age of patients was 19-96 (median 73.1) years, age 65 years or more in $45(75 \%)$ of patients; $29(48.3 \%)$ of patients were females; $24(40 \%)$ of patients had 3 or more comorbidities. The place of residence was home in $44(80 \%)$ of patients and the nursing home in $7(11.7 \%)$ of patients. The admission area was $65 \%$ medicine, $30 \%$ shock-trauma unit, and $5 \%$ surgery. A total of $10 \%$ of 


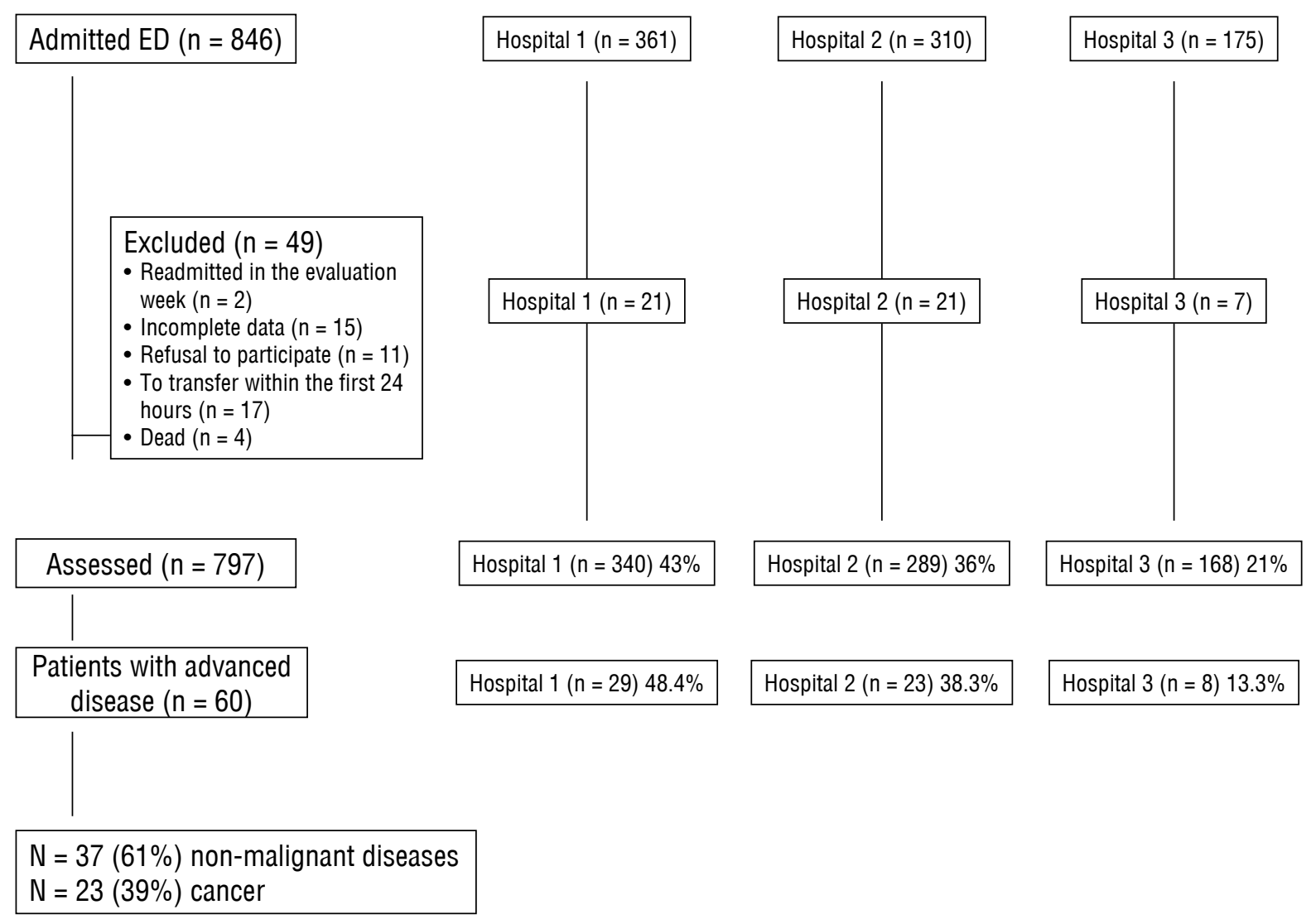

Figure 1. A flowchart of the study. Need for palliative care in 3 emergency departments

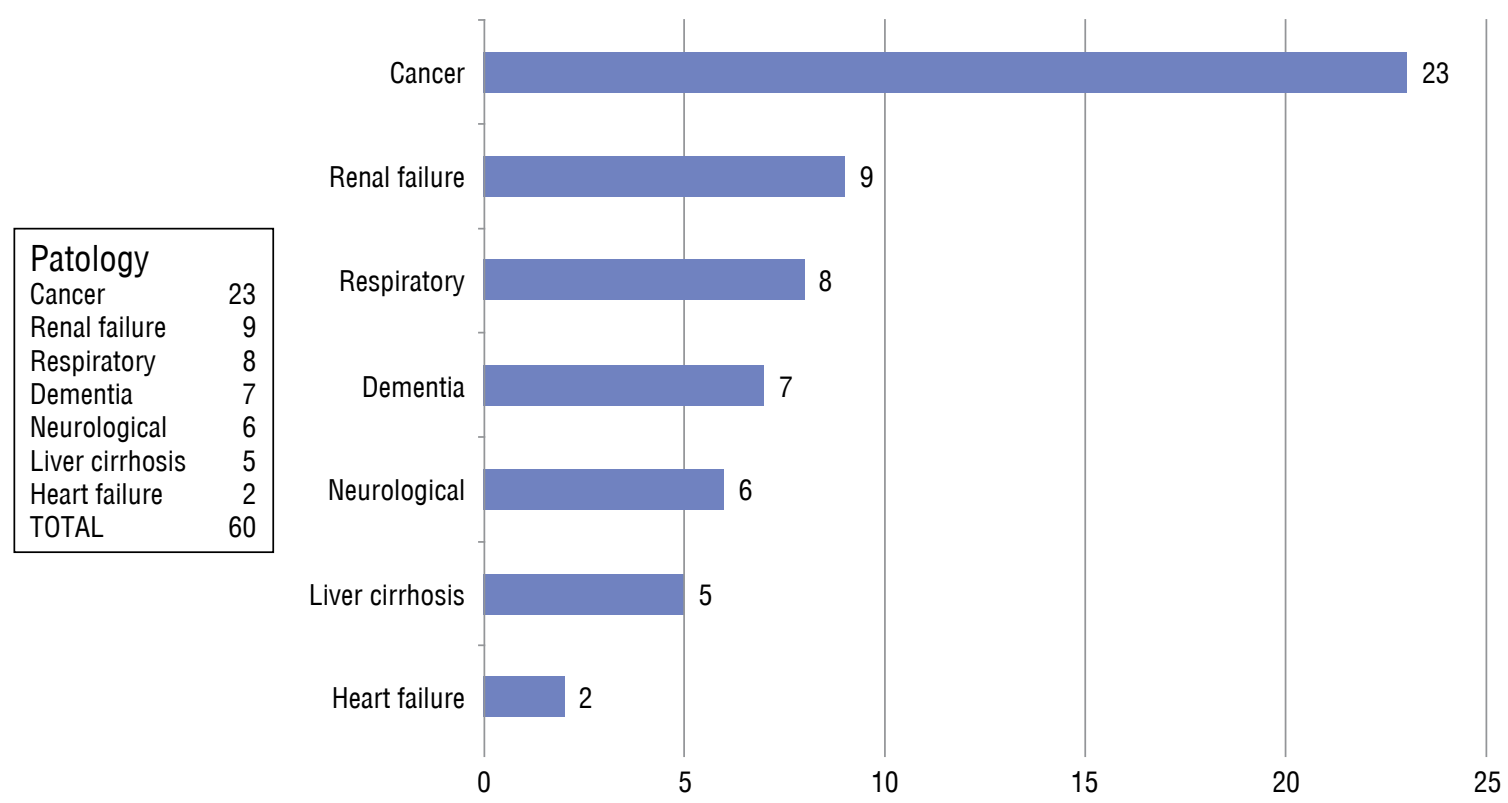

Figure 2. Type of advanced disease. Respiratory proszę podać Pulmonary fibrosis, a zamiast neurological - Stroke and trauma

patients were admitted to an emergency intermediate care unit. In 26 (43.3\%) of patients physicians indicated that they would not be surprised if the patients would die within 12 months (Table 1).
The most prevalent clinical characteristic upon admission was uncontrolled symptoms in 52 (86.7\%) patients, with the most frequent being dyspnoea in $25(42 \%)$ patients, somnolence in $13(22 \%)$, and pain 
Table 1. Frequency of unsatisfied palliative care needs and other characteristics in terminally ill patients admitted to the emergency room in three tertiary hospitals in Peru

\begin{tabular}{|c|c|c|}
\hline \multirow[t]{2}{*}{ Question } & \multirow{2}{*}{\multicolumn{2}{|c|}{$n=60$}} \\
\hline & & \\
\hline $\begin{array}{l}\text { You would be surprised if the patient } \\
\text { died }\end{array}$ & 26 & 43,3 \\
\hline You know what palliative care is & 11 & 18,3 \\
\hline The patient needs palliative care & 50 & 80,3 \\
\hline $\begin{array}{l}\text { You requested palliative care for the } \\
\text { patient }\end{array}$ & 12 & 20,0 \\
\hline Your patient uses palliative care & 13 & 21,7 \\
\hline The symptoms are controlled & 8 & 13,3 \\
\hline Your patient has a caregiver & 55 & 91,7 \\
\hline
\end{tabular}

in $11(18 \%)$ patients with abdominal and thoracic being the most frequent primary tumour locations. Total functional dependence was identified in 44 (73\%) of patients, severe cognitive deterioration in $24(40 \%)$ of patients, and cachexia in 12 (20\%) of patients. A total of $16(27 \%)$ patients responded directly with understandable oral language, the rest presented cognitive impairment or severity of the disease.

The demand for palliative care showed unmet palliative care needs and other characteristics in patients with advanced diseases admitted to ED (Table 1). In 26 (43.3\%) of patients physicians indicated that they would not be surprised if the patients would die within 12 months. A total of 55 (91.7\%) patients had caregivers; $83.6 \%$ of caregivers were permanent and in 48 (80\%) patients these were close relatives (sons, daughters or partners). A total of $46(77 \%)$ of patients who were receiving palliative care mentioned pain treatment; 14 (23\%) of patients were included in a home oncology program with weekly visits, 32 (54\%) of patients in a non-oncological domiciliary program of monthly visits, and the remaining 14 (23\%) of patients in an outpatient program.

\section{Discussion}

ED have the main task of treating emergency acute patients. The present study found that patients with chronic advanced disease frequently enter ED (7.5\% of total admissions) with symptoms that need treatment in 3 of the largest social security hospitals of the country. Non-oncological diseases were more frequent than oncological ones, similarly to other reports [2, 4, 13]; however, local and regional data are limited. The characteristics of these patients such as being older than 65 years, presenting comorbidities, home origin were similar to those reported in other studies $[2,5,6,8,13]$. A high proportion of patients with advanced disease passed through the shock-trauma unit, probably due to their poor clinical condition, and despite their bad prognosis, they were referred to critical units of ED, probably receiving futile treatment not oriented to palliative care goals and not beneficial for patients. This would be influenced by the fact that no advance directives regarding death have been developed and implemented in our country.

Palliative care represents an important benefit for the quality of life of patients with advanced chronic diseases [4]. Indeed, 50 (80\%) of the identified patients referred to needing it. However, only 11 (18.3\%) patients new what palliative care is, $12(20 \%)$ requested palliative care for patients, and $13(21.7 \%)$ mentioned having used it at some time of their disease — data that are similar to that reported in North America $[1,3,8]$. This reflects the poor knowledge that patients and their relatives have regarding this fundamental right. This issue has also been described among health personnel that attend the ED, being a pending issue for future education and research [1]. Moreover, in our study only in $8(13.3 \%)$ of patients symptoms were controlled.

Worldwide, the availability and access to palliative care may vary and mainly depends on the development of the local healthcare system. The present study found that less than a quarter of patients who considered needing palliative care had ever requested it. Those who received this type of care, were mainly focused on pain treatment, with poor control of other symptoms. Less than $50 \%$ of family members or caregivers had internalized the proximity of death, although the majority of direct family members' participated in the care of these patients with advanced diseases [14].

Limitations comprise the fact that the study was carried out in social security hospitals (assigned to $34 \%$ of the national population) and for a short period of time (one week in each establishment). Only $16(27 \%)$ of surveyed patients responded directly with understandable oral language, the rest presented cognitive impairment or severity of the disease. Despite these limitations, to the best of our knowledge this is the first study, which demonstrated the need for palliative care in ED in Peru, seeking to improve the quality of care for this group of patients. Further research and training are needed in this regard $[8,15]$.

\section{Conclusions}

A total of $7.5 \%$ of patients admitted to ED of 3 tertiary care centres presented symptoms and needed appropriate treatment, among which patients 
with non-cancer diseases were more frequent. In these cases, more than $80 \%$ reported the need of palliative care and less than a quarter mentioned having received it. Therefore, it is to be expected that patients with advanced disease will come to the ED in our country, frequently with urgent or non-urgent symptoms that may have been avoided with adequate primary and home palliative care services. This is why it is necessary to develop adequate palliative care guidelines to provide these patients with the best possible care starting at a primary level [16].

\section{Acknowledgements}

The Authors thank Ada Maguiña and Carlos Cerrón for their collaboration in data collection.

\section{Declaration of conflict of interests}

The Authors declares no conflict of interest.

\section{Funding}

This study has no funding.

\section{References}

1. Van Tricht M, Riochet D, Batard E, et al. Palliative care for patients who died in emergency departments: analysis of a multicentre cross-sectional survey. Emerg Med J. 2012; 29(10): 795-797, doi: 10.1136/emermed-2011-200513, indexed in Pubmed: 21965176.

2. Lafond $\mathrm{P}$, Chalayer E, Roussier M, et al. A Hospice and Palliative Care Bed Dedicated to Patients Admitted to the Emergency Department for End-of-Life Care. Am J Hosp Palliat Care. 2016; 33(4): 403-406, doi: 10.1177/1049909114562947, indexed in Pubmed: 25500432.

3. Wong J, Gott M, Frey R, et al. What is the incidence of patients with palliative care needs presenting to the Emergency Department? a critical review. Palliat Med. 2014; 28(10): 1197-1205, doi: 10.1177/0269216314543318, indexed in Pubmed: 25118197.

4. Gómez AM, Romo EG, Vega SB, et al. Análisis de la evolución de pacientes en probable situación de últimos días en un servicio de Urgencias. Medicina Paliativa. 2013; 20(1): 10-18, doi: 10.1016/j.medipa.2012.01.011.

5. Henson LA, Gao W, Higginson IJ, et al. Emergency department attendance by patients with cancer in their last month of life: a systematic review and meta-analysis. J Clin Oncol. 2015; 33(4): 370-376, doi: 10.1200/JCO.2014.57.3568, indexed in Pubmed: 25534384.

6. Alsirafy SA, Raheem AA, Al-Zahrani AS, et al. Emergency Department Visits at the End of Life of Patients
With Terminal Cancer: Pattern, Causes, and Avoidability. Am J Hosp Palliat Care. 2016; 33(7): 658-662, doi: 10.1177/1049909115581819, indexed in Pubmed: 25877944.

7. Wang L, Piet L, Kenworthy CM, et al. Association between palliative case management and utilization of inpatient, intensive care unit, emergency department, and hospice in Medicaid beneficiaries. Am J Hosp Palliat Care. 2015; 32(2): 216-220, doi: 10.1177/1049909113520067, indexed in Pubmed: 24445151.

8. Ouchi $\mathrm{K}, \mathrm{Wu} \mathrm{M}$, Medairos $\mathrm{R}$, et al. Initiating palliative care consults for advanced dementia patients in the emergency department. J Palliat Med. 2014; 17(3): 346-350, doi: 10.1089/jpm.2013.0285, indexed in Pubmed: 24387752.

9. Alonso A, Rexach L, Gisbert A. Criterios de selección de pacientes con enfermedades no oncológicas en programas y/o servicios de cuidados paliativos. Med Paliativa. 2010; 17(3): 161-171.

10. Moyano J, Zambrano S, Mayungo T. Characteristics of the last hospital stay in terminal patients at an acute care hospital in Colombia. Am J Hosp Palliat Care. 2010; 27(6): 402-406, doi: 10.1177/1049909110362522, indexed in Pubmed: 20360598.

11. Alva RV, Tineo JA, Calderón FR, et al. Sobredemanda de atención médica en el servicio de emergencia de adultos de un hospital terciario, Lima, Perú. Anales de la Facultad de Medicina. 2016; 77(4): 379, doi: 10.15381/anales. v77i4.12654.

12. Amado JP, Vasquez R, Huari RW, et al. Patients with End-stage Oncologic and Nononcologic Disease in Emergency Service of an Urban Tertiary Hospital. Indian J Palliat Care. 2018; 24(1): 25-27, doi: 10.4103/IJPC.IJPC_108_17, indexed in Pubmed: 29440802.

13. Gómez-Batiste $X$, Martínez-Muñoz M, Blay $C$, et al. Identifying patients with chronic conditions in need of palliative care in the general population: development of the NECPAL tool and preliminary prevalence rates in Catalonia. BMJ Support Palliat Care. 2013; 3(3): 300-308, doi: 10.1136/bmjspcare-2012-000211, indexed in Pubmed: 24644748.

14. Pastrana T, Torres-Vigil I, De Lima L. Palliative care development in Latin America: an analysis using macro indicators. Palliat Med. 2014; 28(10): 1231-1238, doi: 10.1177/0269216314538893, indexed in Pubmed: 24925578.

15. Lamba S, DeSandre PL, Todd KH, et al. Improving Palliative Care in Emergency Medicine Board. Integration of palliative care into emergency medicine: the Improving Palliative Care in Emergency Medicine (IPAL-EM) collaboration. J Emerg Med. 2014; 46(2): 264-270, doi: 10.1016/j.jemermed.2013.08.087, indexed in Pubmed: 24286714.

16. Köstenberger $M$, Neuwersch $S$, Weixler $D$, et al. Prevalence of palliative care patients in emergency departments. Wien Klin Wochenschr. 2019; 131(17-18): 404-409, doi: 10.1007/s00508-019-1530-5, indexed in Pubmed: 31375918. 


\section{Potrzeba opieki paliatywnej}

\section{u pacjentów przyjętych na szpitalne}

\section{oddziały ratunkowe w trzech szpitalach klinicznych w mieście Ameryki} Eacińskiej

Artykuł jest tłumaczeniem pracy: Amado Tineo J.P., Vasquez Alva R., Huari Pastrana R., Huamán Manrique P.Z., Oscanoa Espinoza T. Need for palliative care in patients admitted to emergency departments of three tertiary hospitals: evidence from a Latin-American city. Palliat. Med. Pract. 2020; tom 14, nr 4: 236-240.

Należy cytować wersję pierwotną.

\section{Streszczenie}

Wstęp: Szpitalne oddziały ratunkowe stanowią punkt kontaktowy dla pacjentów w stanie krytycznym. Z doświadczenia wiemy, że niewielka część pacjentów zgłaszających się na szpitalne oddziały ratunkowe ma objawy wymagające opieki paliatywnej. Częstość występowania tego typu przypadków w Peru nie została jednak dotąd określona.

Cele: Celem pracy była ocena częstości występowania zaawansowanego stadium choroby wśród pacjentów przyjmowanych na szpitalne oddziały ratunkowe oraz zidentyfikowanie zapotrzebowania na opiekę paliatywną wśród tych pacjentów.

Pacjenci i metody: $U$ wszystkich pacjentów przyjmowanych na oddziały ratunkowe trzech szpitali klinicznych $w$ Limie przeprowadzono wywiad medyczny oraz wywiady z ich opiekunami. Za zaawansowane stadium nowotworu uznawano obecność licznych przerzutów, natomiast w przypadku chorób nieonkologicznych uwzględniano demencję i choroby neurologiczne, układu oddechowego, wątroby i serca z towarzyszącą im zależnością funkcjonalną lub poważnym pogorszeniem. Narzędziem badawczym był zwalidowany oraz zaadaptowany kwestionariusz opieki paliatywnej.

Wyniki: Częstość występowania chorób w zaawansowanym stadium wynosiła 7,5\% (60 pacjentów na 797 przyjęć). Wiek pacjentów wahał się od 19 do 96 lat (średnia 73,1 lata). Wśród nich 48,3\% było kobietami, u 23 (39\%) pacjentów występowały choroby onkologiczne, a u 37 (61\%) pacjentów - nieonkologiczne. Najczęstszymi objawami występującymi w chwili przyjęcia były duszności, senność i ból. Łącznie 13 (21,7\%) pacjentów z zaawansowaną postacią choroby było już objętych opieką paliatywną, a u 8 (13,3\%) objawy były kontrolowane.

Wnioski: Niemal 1 na 13 pacjentów przyjętych na oddziały ratunkowe szpitali klinicznych cierpi na zaawansowaną postać choroby, a 80\% zgłasza potrzebę opieki paliatywnej, którą otrzymuje mniej niż jedna czwarta z nich. Palliat Med Pract 2020; 14, 4: 241-246

Słowa kluczowe: zaawansowane stadium choroby, opieka paliatywna, potrzeba i zapotrzebowanie na usługi zdrowotne, szpitalne oddziały ratunkowe

\section{Adres do korespondencji:}

Pilar Zelma Huamán Manrique

UNMSM. Wydział Medycyny, German Amezaga 375, Lima 15081 Lima, Peru

e-mail: pilarzelma.huaman@unmsm.edu.pe 


\section{Wstęp}

Szpitalne oddziały ratunkowe (SOR) mają za zadanie ratować życie i zapobiegać przedwczesnej śmierci pacjentów. Mimo to w ciągu ostatnich kilkudziesięciu lat wzrosła liczba pacjentów w zaawansowanych stadiach chorób przewlekłych (onkologicznych lub nieonkologicznych) wymagających opieki paliatywnej w zakresie tych usług ochrony zdrowia, w szczególności w szpitalach klinicznych [1-5]. Choroby przewlekłe w zaawansowanym stadium wiążą się z wysoką wielochorobowością, zwiększonym zapotrzebowaniem na leki, wyższym poziomem zależności funkcjonalnej, podobnym poziomem pogorszenia funkcji poznawczych oraz zwiększonym zapotrzebowaniem na usługi z zakresu opieki zdrowotnej. Pojedyncze doniesienia wskazują, że 33\% pacjentów z zaawansowanym stadium choroby umiera na oddziałach ratunkowych [2], 31\% było na takim oddziale w ciągu 6 miesięcy przed śmiercią, a $70 \%$ w ostatnim roku życia [3]. Ponadto, 20\% wizyt pacjentów onkologicznych na SOR uznaje się za zbędne [6].

W zaawansowanym stadium choroby przewlekłej nie ma możliwości reakcji leczniczej lub jest ona ograniczona, nawet przy zastosowaniu najlepszego dostępnego leczenia. W takich przypadkach rekomenduje się opiekę paliatywną, uznawaną za odpowiednią zarówno dla pacjentów, jak i ich rodzin. Opieka ta musi obejmować łagodzenie objawów somatycznych i psychologicznych, a także wsparcie emocjonalne i społeczne, w tym wczesną identyfikację potrzeb, również na SOR [8].

Potrzeba świadczenia opieki paliatywnej na oddziałach ratunkowych nie jest dostatecznie dobrze znana [3]. Istnieją doniesienia wskazujące, że 57\% pacjentów zmarłych na oddziałach ratunkowych (u których istniały wskazania do niestosowania resuscytacji) otrzymało opiekę paliatywną [1]. Opieka paliatywna jest lepiej zbadana wśród pacjentów chorujących na nowotwory. Mimo że przewlekłe schorzenia nienowotworowe (niewydolności organów i choroby neurodegeneracyjne) występują częściej i trwają dłużej, istnieje niewiele doniesień dotyczących stosowania opieki paliatywnej w tej populacji pacjentów [9], a badania przeprowadzone w Ameryce Łacińskiej są nieliczne [10]. Niniejsze badanie ma na celu oszacowanie częstości występowania chorób w zaawansowanym stadium wśród pacjentów przyjmowanych na oddziały ratunkowe szpitali klinicznych w Limie w Peru oraz określenie potrzeby opieki paliatywnej u tych pacjentów.

\section{Pacjenci i metody}

Niniejsze badanie przekrojowe przeprowadzono w trzech szpitalach klinicznych w Limie (Peru), w których notuje się 15 000-22 000 przyjęć rocznie [11]. Obecność chorób w zaawansowanym stadium oceniano u pacjentów w wieku lat 18 i starszych, przyjmowanych na oddziały ratunkowe przez 7 kolejnych dni w listopadzie 2016 roku. Stadium choroby nowotworowej określano jako zaawansowane, jeżeli istniały liczne przerzuty do mózgu, wątroby i płuc, potwierdzone patologią anatomiczną. Następujące przypadki uznawano za choroby nieonkologiczne w zaawansowanym stadium:

1. wcześniejsza diagnoza demencji oraz chorób neurologicznych, a także obecność poważnego upośledzenia funkcji poznawczych zdiagnozowana na podstawie testu Pfeiffera lub całkowita zależność funkcjonalna wykazana na podstawie wskaźnika Katza;

2. przewlekła niewydolność nerek z filtracją kłębuszkową poniżej $30 \mathrm{ml} / \mathrm{min}$ oraz całkowita zależność funkcjonalna;

3. przewlekła choroba układu oddechowego z ciągłym podawaniem tlenu w warunkach domowych;

4. marskość wątroby w stadium C (skala Child-Pugh);

5. przewlekła niewydolność serca z frakcją wyrzutową komór poniżej 20\% [9].

Wielkość próby obliczono w celu oszacowania 293 przyjęć, oczekiwany odsetek 21\% [12], poziom ufności $95 \%$, dokładność $5 \%$ i strata 15\%. Z badania wykluczono pacjentów powtórnie przyjętych w tygodniu, w którym przeprowadzano badanie, pacjentów z niekompletnymi danymi, pacjentów, którzy odmówili uczestnictwa, zmarłych pacjentów oraz pacjentów przeniesionych w ciągu pierwszych 24 godzin. Wybrano wszystkich możliwych uczestników. Dwóch przeszkolonych studentów medycyny analizowało codzienne raporty lub protokoły przyjęć, a jeden z pięciu lekarzy (dwóch specjalistów z zakresu chorób wewnętrznych oraz trzech lekarzy SOR z ponad 5-letnim doświadczeniem) prosił o wyrażenie świadomej zgody, analizował szpitalną dokumentację medyczną i przeprowadzał wywiady z pacjentami lub ich opiekunami, wypełniając utworzony wcześniej formularz. Ewentualne wątpliwości rozwiązywano w drodze konsensusu.

Potrzebę opieki paliatywnej wśród pacjentów w zaawansowanym stadium choroby oceniano za pomocą zaadaptowanego, na wpół ustrukturyzowanego kwestionariusza [13], który rozpoczynał się od pytań dotyczących reakcji na śmierć oraz weryfikował wiedzę na temat tego, czym jest opieka paliatywna, w tym zapotrzebowanie na nią i jej zastosowanie. Jeżeli pacjent nie wiedział, co oznacza termin „opieka paliatywna”, wyjaśniano mu go. Badanie zatwierdzono opinią ekspertów (odpowiedni stopień zgodności wśród 3 specjalistów, współczynnik W Kendalla 0,884) oraz miało 

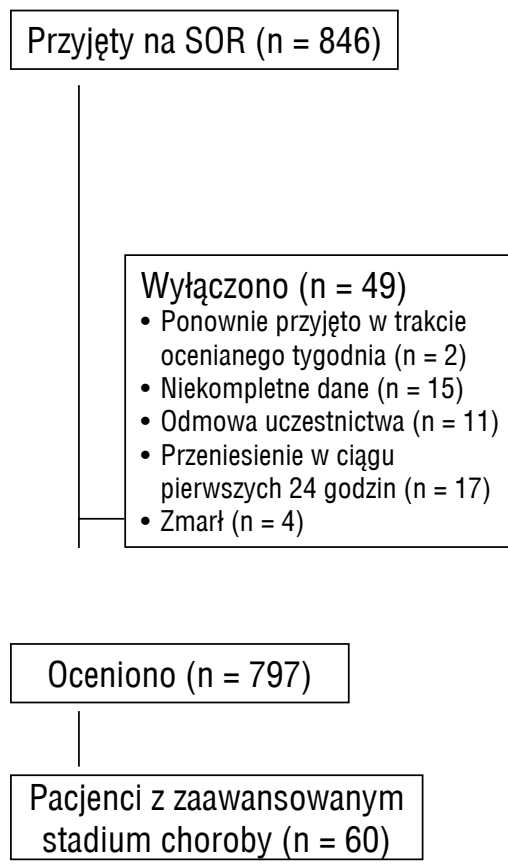

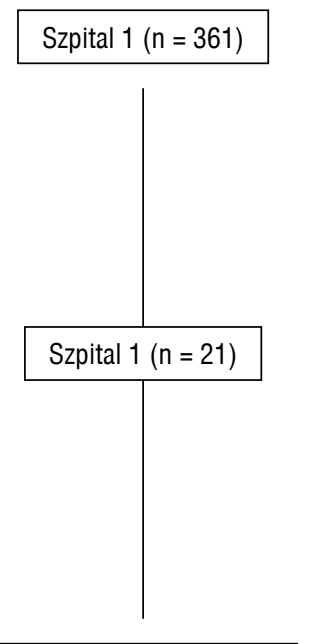

Szpital $1(n=340) 43 \%$

Szpital $1(n=29) 48.4 \%$

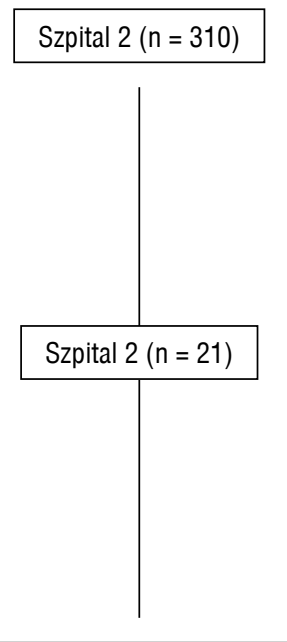

Szpital 2 ( $n=289) 36 \%$

Szpital $2(n=23) 38.3 \%$
Szpital $3(n=175)$

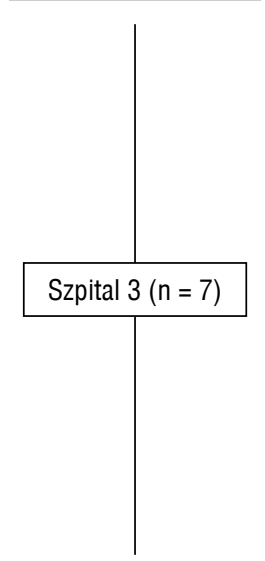

Szpital $3(n=168) 21 \%$

Szpital $3(n=8) 13.3 \%$

$\mathrm{N}=37(61 \%)$ choroby nieonkologiczne

$\mathrm{N}=23(39 \%)$ nowotwór

Rycina 1. Schemat blokowy badania Potrzeba opieki paliatywnej na trzech oddziałach SOR

akceptowalną wewnętrzną spójność (wiarygodność), z alfą Cronbacha 0,699 w teście pilotażowym przeprowadzonym z udziałem 20 pacjentów nieuwzględnionych w badaniu. Dane przeanalizowano, zakodowano i przetworzono z wykorzystaniem programu SPSS-IBM 24.00. Wykonano opisową analizę statystyczną i obliczono 95\% przedziały ufności. Uzyskano zgodę komisji bioetycznej komitetu badawczego instytutu, zgodnie z zasadami dobrej praktyki klinicznej.

\section{Wyniki}

Podczas trwania badania początkowo przyjęto na SOR 846 pacjentów, spośród których 49 zostało z różnych powodów wykluczonych (ryc. 1). Wśród 797 przyjętych pacjentów zidentyfikowano łącznie 60 osób (7,5\%, przedział ufności 5,5-9,0\%) z zaawansowanymi schorzeniami. Odsetki chorych w szpitalu 1, 2 i 3 wynosiły odpowiednio 340 (43\%), 289 (36\%) i 168 (21\%) pacjentów. Łącznie 37 pacjentów (61\%) cierpiało na schorzenia nieonkologiczne, w tym niewydolność nerek (cukrzyca), choroby układu oddechowego (zwłóknienie płuc), demencję (typu alzheimerowskiego oraz naczyniowego), choroby neurologiczne (udary i urazy), marskość wątroby (alkoholizm) i niewydolność serca. Guzy złośliwe zdiagnozowano u 23 pacjentów (39\%). Najczęściej zlokalizowane były w układzie moczowo-płciowym oraz trawiennym (ryc. 2).

Pacjenci byli w wieku 19-96 lat (średnia 73,1 lat), 45 pacjentów (75\%) miało 65 lat i więcej; 29 pacjentów $(48,3 \%)$ to kobiety; 24 pacjentów (40\%) miało trzy lub więcej chorób towarzyszących. Miejscem zamieszkania 44 pacjentów (80\%) był ich dom, natomiast $7(11,7 \%)$ mieszkało $w$ domach opieki. Na oddział wewnętrzny przyjęto $65 \%$ pacjentów, 30\% znalazło się na oddziale urazowo-wstrząsowym, natomiast 5\% przyjęto na oddział chirurgii. Łącznie 10\% pacjentów przyjęto na oddział ratunkowy. W przypadku 26 pacjentów $(43,4 \%)$ lekarze stwierdzili, że nie byliby zaskoczeni, gdyby śmierć nastąpiła w ciągu 12 miesięcy (tab. 1).

Najczęściej występującą cechą kliniczną w chwili przyjęcia były niekontrolowane objawy występujące u 52 pacjentów (86,7\%), wśród których dominowały: duszność u 25 (42\%), senność u 13 (22\%) oraz ból u 11 (18\%) pacjentów z guzami zlokalizowanymi w jamie brzusznej i klatce piersiowej, które były najczęstszymi pierwotnymi lokalizacjami guzów. Całkowitą zależność funkcjonalną stwierdzono u 44 pacjentów (73\%), znaczne pogorszenie funkcji poznawczych - u 24 pacjentów (40\%), a wyniszczenie - u 12 pa- 


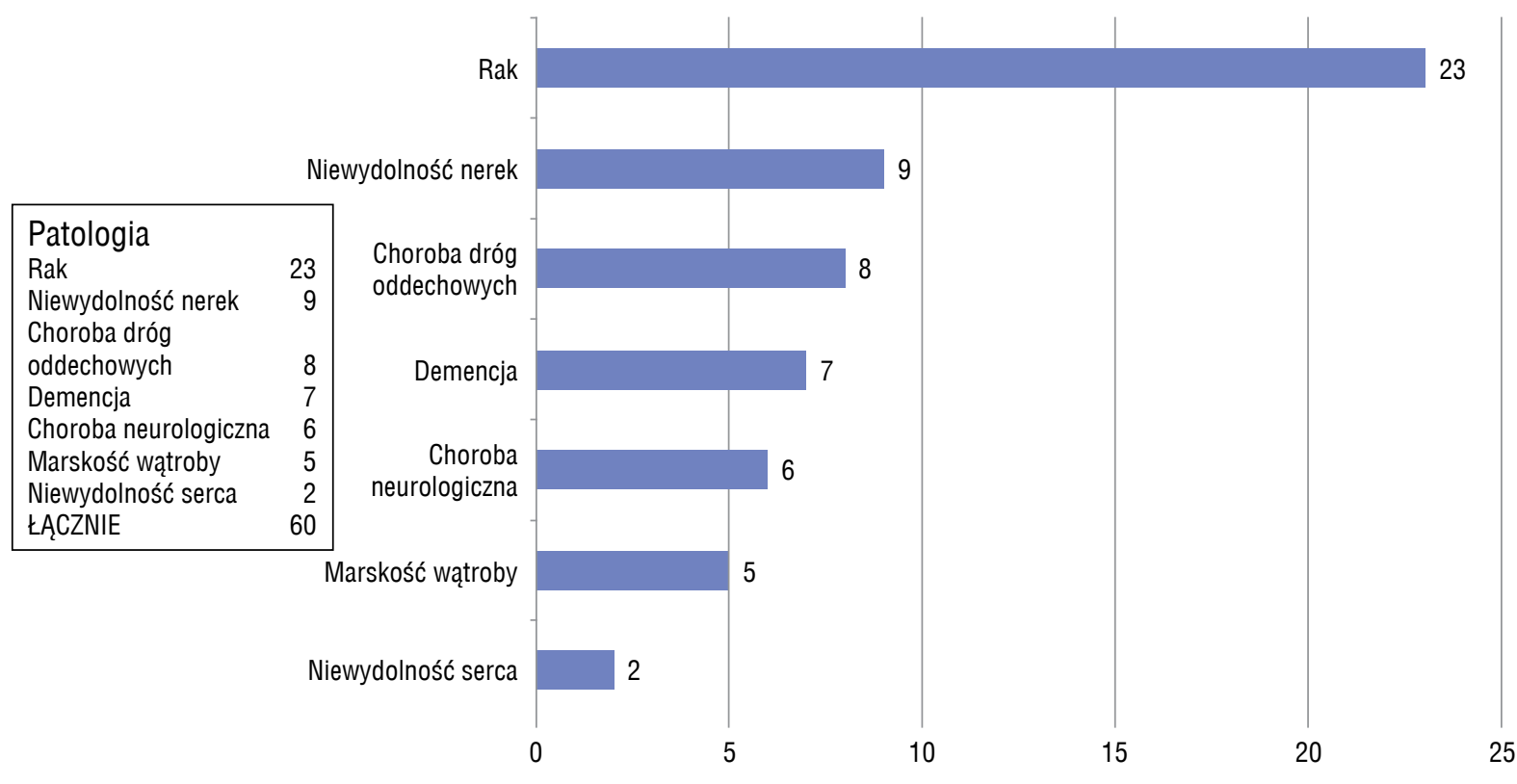

Rycina 2. Rodzaj śmiertelnej choroby

Tabela 1. Częstotliwość występowania przypadków, w których potrzeby pacjentów w zakresie opieki paliatywnej nie zostały zaspokojone i inne cechy charakterystyczne śmiertelnie chorych pacjentów w trzech szpitalach klinicznych w Peru

\begin{tabular}{llc} 
Pytanie & Tak & $\begin{array}{c}\% \\
\text { n }=60\end{array}$ \\
$\begin{array}{lll}\text { Czy byłbyś zaskoczony, gdyby pacjent } \\
\text { zmarł? }\end{array}$ & 26 & 43,3 \\
\hline Czy wiesz, czym jest opieka paliatywna? & 11 & 18,3 \\
\hline Pacjent potrzebuje opieki paliatywnej & 50 & 80,3 \\
\hline $\begin{array}{l}\text { Czy prosit/a pan/i o opiekę paliatywną } \\
\text { dla pacjenta? }\end{array}$ & 12 & 20,0 \\
\hline Czy pacjent otrzymuje opiekę paliatywną? & 13 & 21,7 \\
\hline Czy objawy są kontrolowane? & 8 & 13,3 \\
\hline Czy pacjent ma opiekuna? & 55 & 91,7 \\
\hline
\end{tabular}

cjentów (20\%). Łącznie 16 pacjentów (27) odpowiadało bezpośrednio, zrozumiałym językiem. Reszta wykazywała upośledzenie funkcji poznawczych lub nasilenie choroby.

W zakresie zapotrzebowania na opiekę paliatywną wykazano, że te potrzeby pacjentów nie były zaspokajane; wykazano również inne cechy charakterystyczne pacjentów w zaawansowanym stadium choroby, przyjmowanych na SOR (tab. 1). W przypadku 26 pacjentów $(43,4 \%)$ lekarze stwierdzili, że nie byliby za- skoczeni, gdyby śmierć nastąpiła w ciągu 12 miesięcy (tab. 1). Łącznie 55 pacjentów $(91,7 \%)$ miało opiekunów; 83,6\% opiekunów było stałymi opiekunami, a opiekunowie 48 (80\%) pacjentów byli ich bliskimi krewnymi (synami, córkami lub partnerami). Łącznie 46 pacjentów (77\%) otrzymujących opiekę paliatywną wspomniało o leczeniu bólu; 14 pacjentów (23\%) było objętych programem onkologicznym w warunkach domowych, w ramach którego odbywały się cotygodniowe wizyty, 32 pacjentów (54\%) było objętych programem leczenie nieonkologicznego w warunkach domowych z comiesięcznymi wizytami, a pozostałych 14 pacjentów (23\%) było objętych programem ambulatoryjnym.

\section{Dyskusja}

Głównym zadaniem SOR jest leczenie nagłych przypadków. W niniejszym badaniu zaobserwowano, że pacjenci z przewlekłymi chorobami w zaawansowanym stadium często pojawiają się na SOR $(7,5 \%$ wszystkich przyjęć) z objawami wymagającymi leczenia w trzech z największych szpitali w kraju. Choroby nieonkologiczne występowały częściej niż onkologiczne, podobnie jak w innych doniesieniach [2, 4, 13]. Lokalne dane są jednak ograniczone. Charakterystyka pacjentów (tj. wiek powyżej 65 lat, współwystępowanie chorób, mieszkanie $w$ domu) była podobna do charakterystyki pacjentów przedstawionej w innych 
badaniach $[2,5,6,8,13]$. Wyższy odsetek pacjentów z zaawansowanymi postaciami chorób przechodził przez oddział urazowo-wstrząsowy, prawdopodobnie ze względu na ich zły stan kliniczny. Pomimo złego rokowania, pacjentów tych kierowano na oddziały intensywnej terapii SOR, gdzie prawdopodobnie byli leczeni nieodpowiednio, w sposób niezorientowany na cele opieki paliatywnej i nie przynoszący im korzyści. Wpływ na powyższe może mieć fakt, że w naszym kraju nie opracowano i nie wdrożono żadnych zaawansowanych przepisów dotyczących śmierci.

Opieka paliatywna daje istotne korzyści w zakresie jakości życia pacjentów z chorobami przewlekłymi w zaawansowanym stadium [4]. Rzeczywiście, 50 pacjentów (80\%) potwierdziło, że jest ono im potrzebne. Jednak tylko 11 pacjentów $(18,3 \%)$ wiedziało, czym jest opieka paliatywna, 12 (20\%) prosito o opiekę paliatywną, a $13(21,7 \%)$ podało, że na którymś z etapów choroby była ona u nich stosowana - dane są podobne do podawanych $w$ badaniach dotyczących Ameryki Północnej $[1,3,8]$. Odzwierciedla to zły stan wiedzy pacjentów i ich opiekunów odnośnie tego podstawowego prawa. Problem ten został też opisany wśród personelu medycznego. W przyszłości niezbędna będzie edukacja i badania w tym zakresie [1]. Ponadto tylko u 8 pacjentów $(13,3 \%)$ objętych niniejszym badaniem objawy choroby były kontrolowane.

Dostępność opieki paliatywnej na całym świecie może być różna; w głównej mierze zależy ona od stanu lokalnych systemów opieki zdrowotnej. W niniejszym badaniu zaobserwowano, że mniej niż jedna czwarta pacjentów twierdzących, że potrzebują opieki paliatywnej kiedykolwiek o taką opiekę prosiła. U pacjentów, którzy otrzymywali tego rodzaju opiekę, skupiała się ona gtównie na leczeniu bólu. Inne objawy były kontrolowane w małym stopniu. Mniej niż 50\% członków rodziny lub opiekunów przyjęło fakt bliskości śmierci, pomimo że większość z nich opiekowała się pacjentem $w$ zaawansowanym stadium choroby [14].

Jednym z ograniczeń badania jest fakt, że zostało ono przeprowadzone w szpitalach opieki społecznej (do których przypisane jest 34\% populacji), a także krótki czas trwania badania (jeden tydzień w każdej z placówek). Jedynie 15 pacjentów (27\%) odpowiadało bezpośrednio, używając zrozumiałego języka. Reszta wykazywała upośledzenie funkcji poznawczych lub nasilenie choroby. Pomimo ograniczeń, zgodnie z naszą wiedzą, jest to pierwsze badanie, które przedstawia potrzebę opieki paliatywnej w SOR w Peru, mające na celu poprawę jakości opieki w tej grupie pacjentów. Dalsze badania i szkolenia są w tym zakresie potrzebne [7, 15].

\section{Wnioski}

Łącznie 7,5\% pacjentów przyjętych na SOR w trzech szpitalach klinicznych miało objawy i wymagało odpowiedniego leczenia. Choroby nieonkologiczne występowały częściej. W omawianych przypadkach, ponad 80\% pacjentów zgłaszało potrzebę opieki paliatywnej, a mniej niż jedna czwarta stwierdziła, że taką opiekę otrzymała. Można zatem się spodziewać, że pacjenci ze schorzeniami w zaawansowanym stadium będą pojawiać się na SOR w naszym kraju, często z objawami, których wystąpienia można uniknąć, stosując odpowiednio podstawową i domową opiekę paliatywną. Dlatego też konieczne jest opracowanie odpowiednich wytycznych z zakresu opieki paliatywnej tak, aby zapewnić im najlepszą możliwą opiekę już na poziomie podstawowym [16].

\section{Podziękowania}

Autorzy dziękują Adzie Maguiñii oraz Carlosowi Cerrónowi za współpracę przy zbieraniu danych.

\section{Deklaracja konfliktu interesów}

Wszyscy Autorzy oświadczają, że nie występuje konflikt interesów.

\section{Finansowanie}

Niniejsze badanie nie zostało sfinansowane.

\section{Piśmiennictwo}

1. Van Tricht M, Riochet D, Batard E, et al. Palliative care for patients who died in emergency departments: analysis of a multicentre cross-sectional survey. Emerg Med J. 2012; 29(10): 795-797, doi: 10.1136/emermed-2011-200513, indexed in Pubmed: 21965176.

2. Lafond $\mathrm{P}$, Chalayer $\mathrm{E}$, Roussier M, et al. A Hospice and Palliative Care Bed Dedicated to Patients Admitted to the Emergency Department for End-of-Life Care. Am J Hosp Palliat Care. 2016; 33(4): 403-406, doi: 10.1177/1049909114562947, indexed in Pubmed: 25500432.

3. Wong J, Gott M, Frey R, et al. What is the incidence of patients with palliative care needs presenting to the Emergency Department? a critical review. Palliat Med. 2014; 28(10): 1197-1205, doi: 10.1177/0269216314543318, indexed in Pubmed: 25118197.

4. Gómez AM, Romo EG, Vega SB, et al. Análisis de la evolución de pacientes en probable situación de últimos días en un servicio de Urgencias. Medicina Paliativa. 2013; 20(1): 10-18, doi: 10.1016/j.medipa.2012.01.011.

5. Henson LA, Gao W, Higginson IJ, et al. Emergency department attendance by patients with cancer in their last month of life: a systematic review and meta-analysis. J Clin Oncol. 2015; 33(4): 370-376, doi: 10.1200/JCO.2014.57.3568, indexed in Pubmed: 25534384.

6. Alsirafy SA, Raheem AA, Al-Zahrani AS, et al. Emergency Department Visits at the End of Life of Patients With Terminal Cancer: Pattern, Causes, and Avoidability. Am J Hosp Palliat Care. 2016; 33(7): 658-662, 
doi: 10.1177/1049909115581819, indexed in Pubmed: 25877944.

7. Wang L, Piet L, Kenworthy CM, et al. Association between palliative case management and utilization of inpatient, intensive care unit, emergency department, and hospice in Medicaid beneficiaries. Am J Hosp Palliat Care. 2015; 32(2): 216-220, doi: 10.1177/1049909113520067, indexed in Pubmed: 24445151.

8. Ouchi K, Wu M, Medairos R, et al. Initiating palliative care consults for advanced dementia patients in the emergency department. J Palliat Med. 2014; 17(3): 346-350, doi: 10.1089/jpm.2013.0285, indexed in Pubmed: 24387752.

9. Alonso A, Rexach L, Gisbert A. Criterios de selección de pacientes con enfermedades no oncológicas en programas y/o servicios de cuidados paliativos. Med Paliativa. 2010; 17(3): 161-171.

10. Moyano J, Zambrano S, Mayungo T. Characteristics of the last hospital stay in terminal patients at an acute care hospital in Colombia. Am J Hosp Palliat Care. 2010; 27(6): 402-406, doi: 10.1177/1049909110362522, indexed in Pubmed: 20360598.

11. Alva RV, Tineo JA, Calderón FR, et al. Sobredemanda de atención médica en el servicio de emergencia de adultos de un hospital terciario, Lima, Perú. Anales de la Facultad de Medicina. 2016; 77(4): 379, doi: 10.15381/anales.v77i4.12654.

12. Amado JP, Vasquez R, Huari RW, et al. Patients with End-stage Oncologic and Nononcologic Disease in Emergency
Service of an Urban Tertiary Hospital. Indian J Palliat Care. 2018; 24(1): 25-27, doi: 10.4103/IJPC.IJPC_108_17, indexed in Pubmed: 29440802.

13. Gómez-Batiste X, Martínez-Muñoz M, Blay C, et al. Identifying patients with chronic conditions in need of palliative care in the general population: development of the NECPAL tool and preliminary prevalence rates in Catalonia. BMJ Support Palliat Care. 2013; 3(3): 300-308, doi: 10.1136/bmjspcare-2012-000211, indexed in Pubmed: 24644748.

14. Pastrana T, Torres-Vigil I, De Lima L. Palliative care development in Latin America: an analysis using macro indicators. Palliat Med. 2014; 28(10): 1231-1238, doi: 10.1177/0269216314538893, indexed in Pubmed: 24925578.

15. Lamba S, DeSandre PL, Todd KH, et al. Improving Palliative Care in Emergency Medicine Board. Integration of palliative care into emergency medicine: the Improving Palliative Care in Emergency Medicine (IPAL-EM) collaboration. J Emerg Med. 2014; 46(2): 264-270, doi: 10.1016/j.jemermed.2013.08.087, indexed in Pubmed: 24286714.

16. Köstenberger $M$, Neuwersch $S$, Weixler $D$, et al. Prevalence of palliative care patients in emergency departments. Wien Klin Wochenschr. 2019; 131(17-18): 404-409, doi: 10.1007/s00508-019-1530-5, indexed in Pubmed: 31375918. 